\title{
PENGARUH PENGGUNAAN MEDIA 3D SIENCE BERBASIS ANDROID DENGAN MODEL PEMBELAJARAN KOOPERATIF TERHADAP HASIL BELAJAR BIOLOGI SIWA KELAS VIII DI MTs NEGERI 1 MAROS BARU
}

\author{
Kalsum ${ }^{1}$ \\ Universitas Muslim Maros/kalsumkalsum04@gmail.com
}

\begin{abstract}
Abstrak
Penelitian ini termasuk penelitian Quasy Eksperimental. Penelitian ini bertujuan untuk mengetahui bagaimana pengaruh penggunaan media 3D Science Berbasis Android Dengan Model Pembelajaran Kooperatif terhadap hasil belajar biologi kelas VIII MTs Negeri 1 Maros pada materi sistem pernafasan. Variabel bebas dalam penelitian ini adalah penggunaan Media 3D Science Berbasis Android sedangkan variabel terikat dalam penelitian ini adalah hasil belajar biologi peserta didik.Data dianalisis menggunakan Analisis uji Deskriptive, Normalitas, Homogenitas, Hipotesis, dan Ngain dengan menggunakan SPSS versi 16. Pada penelitian ini dapat disimpulkan bahwa ada pengaruh penggunaan Media 3D Science Berbasis Android Dengan Model PembelajaranKooperatif terhadap hasil belajar biologi. Hal ini juga di buktikan dari hasil perolehan pengujian hipotesis dengan menggunakan uji-t yaitu diperoleh nilai thitung= 13.380 lebih besar dari ttabel $=1,66$ dengan taraf signifikan 0,05 atau 5\%. Selain itu dilihat dari hasil perhitungan postes setelah diberikan perlakuan media pembelajaran 3D Science Berbasis Android sebanyak empat pertemuan dengan nilai rata-rata 85,71, lebih tinggi dibandingkan dengan hasil perhitungan postes kelas kontrol dengan nilai rata-rata 77,50 yang diberikan perlakuan sebanyak empat kali pertemuan dengan menggunakan media pembelajaran dua dimensi.
\end{abstract}

Kata Kunci : Media 3D Science Berbasis Android, Hasil Belajar Siswa.

\begin{abstract}
This research is an experimental Quasy study. This study aims to determine how the influence of the use of 3D media based on AndroidScience with Cooperative Learning Models to the learning outcomes of biology class VIII MTs Negeri 1 Maros on the material of the respiratory system. The independent variable in this study is the use of Android-based 3D Science Media while the dependent variable in this study is the learning outcomes of students' biology. Data were analyzed using Descriptive Test Analysis, Normality, Homogeneity, Hypothesis, and Ngain using SPSS version 16. In this study can it was concluded that there was an influence of the use of Android-based 3D Science Media with Cooperative Learning Models on biology learning outcomes. This is also evidenced from the results of obtaining a hypothesis test using the t-test that is obtained tcount $=13.380$ is greater than ttable $=1.66$ with a significant level of 0.05 or $5 \%$. Also seen from the results of the posttest calculation after being given treatment of 3D Science-based learning media Android as many as four meetings with an average value of 85.71, higher than the results of the calculation of posttest control classes with
\end{abstract}


an average value of 77.50 given four treatments meeting times using two-dimensional learning media

Keywords: 3D Science Based on Android, Student Learning Outcomes.

\section{PENDAHULUAN}

Kegiatan belajar mengajar merupakan proses pembentukan pemahaman diri siswa akan ilmu dan perkembangan baik secara pengetahuan, psikis maupun sosial. Tujuan dari proses pembelajaran meliputi berbagai aspek yang ditetapkan sebagai hasil dari pembelajaran itu sendiri salah satunya adalah aspek kognitif.

Aspek kognitif merupakan kemampuan inteektual siswa dalam berpikir, mengetahui dan memecahkan suatu masalah. Salah satunya mata pelajaran biologi yang banyak menggunakkan alat peraga yang memiliki harga yang cukup tinggi, sehingga tidak mencukupi untuk penggunaan kegiatan pembelajaran. Karenanya pada mata pelajaran biologi para siswa perlu diberikan simulasi ataupun contoh dalam setiap pembelajarannya. Oleh karenanya dibutuhkan media pembelajaran yang mampu membantu dalam kegiatan pembelajaran dan dapat dimanfaatkan dengan baik penggunaannya dalam kegiatan pembelajaran. Serta pemanfaatannya dapat memberikan dampak potensial yang dapat meningkatkan kualitas dalam belajar.

Perkembangan sistem operasi android, mulai dari gadget, tablet PC, smartphone dan aplikasi lain yang memiliki sistem operasi android lainnya. Tentunya dapat mendukung peserta didik memiliki dan menggunakan android dalam kehidupan sehari-hari. Penggunaan smartphone sendiri tengah populer di dunia dan tidak ketinggalan dengan Indonesia. Dengan adanya smartphone dapat memberikan dampak yang sangat besar bagi kehidupan manusia dan memberikan banyak kemudahan dalam penggunaannya.

Menurut Purbasari (Rizki Suhendar dkk, 2017:201) Perkembangan ilmu pengetahuan dan teknologi mengarah pada perubahan yang semakin signifikan dan menuju era praktis. Dalam sektor pendidikan, perkembangan teknologi informasi merambah pada sistem pengelolaan dan juga sistem pembelajaran di kelas. Pemanfaatan media yang semakin bervariasi menjadi tantangan guru dalam melaksanakan 
tugasnya sebagai pengajar di sekolah dalam rangka mencapai tujuan pembelajaran.

Belajar merupakan hal yang kompleks. Kompleksitas belajar tersebut dipandang dari dua subjek, yaitu dari peserta didik dan dari pendidik. Dari segi siswa, belajar dialami sebagai suatu proses mental dalam mengahadapi bahan belajar. Sedangkan dari segi pendidik, proses belajar tersebut tampak sebagai perilaku belajar tentang sesuatu hal.

Menurut Panen (Muyaroah dan Fajartia, 2017:80) Belajar adalah suatu proses perubahan yang relatif tetap dalam perilaku individu sebagai hasil dari pengalaman. Sedangkan, menurut Ruhimat (Muyaroah dan Fajartia, 2017:80) Belajar merupakan aktivitas yang disengaja dan dilakukan oleh individu agar terjadi perubahan kemampuan diri, dengan belajar anak yang tadinya tidak mampu melakukan sesuatu, menjadi mampu melakukan sesuatu, atau anak yang tadinya tidak terampil, menjadi terampil. Belajar merupakan kegiatan orang sehari-hari.

"Istila Pembelajaran merupakan perkembangan dari istilah pengajaran, dan istilah belajar-mengajar yang dapat kita perdebatkan, atau kita abaikan saja yang penting makna dari ketiganya.
Menurut Ruhimat, dkk (Muyaroah dan Fajartia, 2017:80) Pembelajaran adalah suatu upaya yang dilakukan oleh seseorang atau pendidik untuk membelajarkan siswa yang belajar. Dalam konsep pendidikan, pembelajaran diartikan sebagai usaha mengelola lingkungan dengan sengaja agar seseorang membentuk diri secara positif dalam kondisi lingkungan tertentu.

Hampir semua anak, termasuk siswa SD/MI, telah memiliki benda dengan sistem operasi android yang tersemat dalam smartphone. Berdasarkan berbagai macam keunggulan yang terdapat dalam sistem android, maka dapat digunakan untuk menciptakan suatu media pembelajaran yang berbasis android dalam materi pembelajaran IPA.

Materi yang akan di kembangkan dalam proses pembuatan media pembelajaran berbasis android tersebut adalah Sistem Pernapasan. Dengan mengembangkan media pembelajaran berbasis android, diharapkan para siswa dapat menggunakannya sebagai salah satu media pembelajaran mandiri untuk mempelajari Sistem Pernapasan di dalam dan di luar kelas. 


\section{METODE PENILITIAN}

Penelitian ini menggunakan jenis penelitian kuantitatif dengan metode eksperimen semu (Quasy experimental research). Dimana peneliti melakukan penelitian secara langsung yaitu dua kelas dimana satu kelas diberikan pembelajaran dengan menggunakan media 3D Sciencedan satu kelas lagi dengan pembelajaran metode ceramah. Penelitian ini digunakan peneliti untuk mengetahui hubungan dua variabel yang digunakan dalam pembelajaran.

Dua variabel tersebut adalah variabel media visual $3 \mathrm{D}$ dan variabel hasil belajar biologi siswa kelas VIII MTs Negeri 1 Maros pada materi sistem Pernafasan manusia.

\section{Desain Penelitian}

Desain penelitian ini menggunakan Nonequivalent Control Grup Design, dalam desain penelitian ini ada dua kelompok yaitu kelas eksperimen dan kelas kontrol. Pada penelitian kelas eksperimen dan kelas kelas kontrol tidak dipilih secara random. Secara rinci Nonequivalent Control Group Desain (Sugiyono, 2011: 116), dapat dilihat pada gambar berikut ini:
Tabel 3.1 Desain Penelitian

$$
\begin{array}{lll}
\mathbf{O}_{1} & \mathrm{X} & \mathbf{O}_{2}
\end{array}
$$

$\mathrm{O}_{3} \quad \mathrm{O}_{4}$

\section{Keterangan:}

$\mathrm{O}_{1} \quad$ : Pretest kelas eksperimen

$\mathrm{O}_{2} \quad$ : Posttest kelas eksperimen

$\mathrm{O}_{3} \quad$ : Pretest kelas kontrol

$\mathrm{O}_{4} \quad$ : Posttes kelas kontrol

$\mathrm{X}$ : Perlakuan dengan penerapan media 3D Science

(Sumber: Sugiono: 2014)

Populasi dalam penelitian ini adalah Siswa kelas VIII MTs Negeri 1 Maros Kecamatan Lau Kabupaten Maros Tahun Ajaran 2018/2019. Populasi dalam penelitian ini terdiri 3 kelas.

Tabel 3.1 Populasi peserta didik

\begin{tabular}{lc}
\hline \multicolumn{2}{l}{ MTsNegeri 1 Maros } \\
\hline Kelas & Jumlah Siswa \\
\hline VIII A & 21 \\
\hline VIII B & 24 \\
\hline VIII C & 24 \\
\hline Total & 69
\end{tabular}

Tehnik pengambilan sampel adalah acak beruntun Multi-Stage Random Sampling (MSRS). MSRS merupakan tehnik penentuan sampel dengan jalan melakukan pengacakan beberapa kali. 
Tabel 3.2 Sampel Siswa

\begin{tabular}{c}
\hline \multicolumn{2}{c}{ MTs Negeri 1 Maros } \\
\hline Kelas Jumlah Siswa \\
\hline VIII A 21 \\
\hline VIII B 24 \\
\hline Total 45
\end{tabular}

\section{HASIL DAN PEMBAHASAN}

Penelitian ini dilaksanakan di MTs Negeri 1 Maros pada dua kelas yaitu kelas VIII A dan kelas VIII B dengan perlakuan yang berbeda untuk mengetahui bagaimana hasil belajar siswa yang menggunakan media dan tidak menggunakan media. Kelas VIII A dikategorikan sebagai kelas eksperimen diberikan perlakuan yaitu Pengaruh Penggunaan Media 3D Science Berbasis Android Terhadap Hasil Belajar Siswa, sedangkan kelas VIII B dikategorika sebagai kelas kontrol diterapkan model pembelajaran konvensional. Penerapan model pembelajaran tersebut pada materi biologi pokok bahasan Pernafasan. Sebelum melakukan penelitian, terlebih dahulu peneliti menyusun rencana pelaksanaan pembelajaran (RPP) yang akan dilaksanakan pada kelas eksperimen maupun kelas kontrol di uji validasinya oleh salah satu dosen biologi FKIP UMMA. Kemudian RPP tersebut dikonsultasikan kepada guru mata pelajaran biologi kelas VIII setelah RPP disetujui oleh guru, maka peneliti segera melakukan penelitian.

Penelitian ini dilakukan selama empat kali pertemuan baik kelas eksperimen maupun kelas kontrol. Satu pertemuan pembelajaran terdiri dari 2 jam pelajaran atau 80 menit. Pada Pertemuan pertama merupakan pemberian pre test dilanjutkan dengan pemberian materi dengan penerapan Media 3D Science berbasis Android untuk kelas eksperimen dan model konvensional untuk kelas kontrol.

Setelah pembelajaran tuntas dilaksanakan sampai pada hari ke empat, peneliti memberikan post test terhadap kedua kelas. Jenis tes yang diberikan adalah tes essay dengan 10 pertayaan yang telah divalidasi (hasil validasi terlampir). Tabel 4.1 Distribusi dan Frekuensi Kategori Hasil Belajar kelas Ekspiremen dan Kelas Kontrol Pre test dan pos test. 


\begin{tabular}{|c|c|c|c|c|c|c|c|c|c|c|}
\hline \multirow[t]{2}{*}{ NO } & \multirow{2}{*}{$\begin{array}{l}\text { Interval } \\
\text { Nilai }\end{array}$} & \multirow{2}{*}{ Kategori } & \multicolumn{2}{|c|}{$\begin{array}{c}\text { Kelas } \\
\text { Eksperimen }\end{array}$} & \multicolumn{2}{|c|}{$\begin{array}{c}\text { Kelas } \\
\text { Kontrol }\end{array}$} & \multicolumn{2}{|c|}{$\begin{array}{c}\text { Rata- } \\
\text { rata }\end{array}$} & \multicolumn{2}{|c|}{ Persen $(\%)$} \\
\hline & & & I & IV & I & IV & EK & $\mathrm{KO}$ & EK & $\mathrm{KO}$ \\
\hline 1 & $0-54$ & $\begin{array}{l}\text { Sangat } \\
\text { Rendah }\end{array}$ & 11 & 0 & 20 & 0 & 5,5 & 10 & $26,1 \%$ & $41,6 \%$ \\
\hline 2 & $55-64$ & Rendah & 5 & 0 & 4 & 0 & 2,5 & 2 & $11,9 \%$ & $8,3 \%$ \\
\hline 3 & $65-79$ & Sedang & 5 & 5 & 0 & 13 & 5 & 6,5 & $23,8 \%$ & $27 \%$ \\
\hline 4 & $80-89$ & Tinggi & 0 & 9 & 0 & 8 & 4,5 & 4 & $21,4 \%$ & $16,6 \%$ \\
\hline 5 & $90-100$ & $\begin{array}{l}\text { Sangat } \\
\text { Tinggi }\end{array}$ & 0 & 7 & 0 & 3 & 3,5 & 1,5 & $16,6 \%$ & $6,25 \%$ \\
\hline
\end{tabular}

Sumber : Khaeruddin Sidin Ali 2012.

Berdasarkan data pada table 4.1 diatas bahwa kategori hasil belajar kelas eksperimen untuk pre-test dan pos-test diperoleh nilai rata-rata untuk kategori yakni sangat rendah yakni 5,5 atau sebesar 26,1\%, pada kategori rendah diperoleh nilai rata-rata 2,5 sebesar $11,9 \%$ pada kategori sedang diperoleh nilai rat-rata 5 sebesar $23,8 \%$, dan pada kategori tinggi diperoleh nilai rata-rata 4,5 sebesar $16,6 \%$ dan kategori sangat tinggi diperoleh nilai rata-rata 3,5 sebesar $16,6 \%$.

Sedangkan kategori hasil belajar kelas kontrol untuk pre-test dan postest diperoleh nilai rata-rata untuk kategori sangat rendah 10 sebesar $41,6 \%$, pada kategori rendah diperoleh nilai rata-rata 2 sebesar $18,3 \%$ pada kategori sedang diperoleh nilai rat-rata 6,5 sebesar $27 \%$, dan pada kategori

tinggi diperoleh nilai rata-rata 4 sebesar $16,6 \%$ dan kategori sangat tinggi diperoleh nilai rata-rata 1,5 sebesar 6,5\%. Perbandingan tersebut dapat pula dilihat pada diagram berikut;

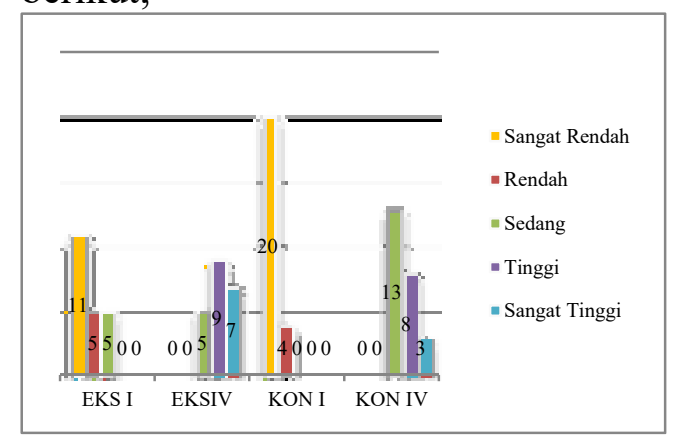

Gambar 4.1. Diagram Batang Hasil pre test dan post test kelas eksperimen dan kelas kintrol

Tabel 4.2 Analisis Deskriptif Hasil Belajar Biologi Peserta Didik Kelas Eksperimen dan Kelas Kontrol

\begin{tabular}{lll}
\hline & $\begin{array}{c}\text { Kelas } \\
\text { Eksperimen }\end{array}$ & $\begin{array}{c}\text { Kelas } \\
\text { Kontrol }\end{array}$ \\
\hline Jumlah Sampel & 21 & 24 \\
Nilai Terendah & 20 & 20 \\
Nilai Tertinggi & 95 & 90 \\
Mean & 85,71 & 77,5 \\
Medium & 85 & 77,5 \\
Range & 20 & 20 \\
Standar Deviasi & 6,182 & 6,065 \\
Varians & 38,124 & 36,783 \\
\hline (Sumber:Hasil analisis deskriptif nilai hasil \\
belajar)
\end{tabular}


Tabel 4.3 Distribusi Tingkat Ketuntasan Hasil Belajar Biologi kelas Eksperimen dan Kelas Kontrol

\begin{tabular}{cccc}
\hline No & Ketuntasan & $\begin{array}{c}\text { Kelas } \\
\text { Eksperimen }\end{array}$ & $\begin{array}{c}\text { Kelas } \\
\text { Kontrol }\end{array}$ \\
\hline $\mathbf{1}$ & Tuntas & 21 & 18 \\
$\mathbf{2}$ & Tidak & 0 & 6 \\
& Tuntas & & \\
\hline
\end{tabular}

Adapun ketuntasan hasil belajar siswa berdasarkan aturan yang telah ditetapkan oleh MTs Negri 1 Maros pada kelas VIII, siswa dikatakan tuntas pada mata pelajaran biologi apabila nilai kreteria ketuntasan minimal (KKM) yaitu 75. Setelah siswa menggunakan media 3D Science pada kelas ekperimen terdapat 21 siswa tuntas dan 0 siswa tidak tuntas atau dibawah standar nilai KKM untuk kelas kontrol menggunakan metode pembelajaran konvensional terdapat 18 siswa tuntas dan 6 siswa tidak tuntas.

Berdasarkan hasil pengujian hipotesis penelitian, diperoleh nilai $\mathrm{t}$ 13.380. Adapun nilai ttabel diperoleh dari tabel distribusi t dengan df (degree of freedom) 40 dan taraf signifikansi $(\alpha)$ $=0,05$ yaitu sebesar 37.246. Dengan membandingkan ttabel dan thitung, diperoleh ttabel $<$ thitung karena $37.246<13,380$ berarti H0 ditolak H1 diterima.
Dengan demikian diketahui bahwa penggunaan media 3D science berbasis android berpengaruh terhadap hasil pembelajaran biologi peserta didik.

Berdasarkan analisis deskriptif, terlihat bahwa penggunaan media pembelajaran tiga dimensi berpengaruh positif terhadap hasil belajar biologi peserta didik . Hal tersebut karena kesesuaian prosedur pelaksanaan yang dimulai dari, pelaksanaan penelitian, dan pengolahan data. Adapun nilai rata-rata kelas eksperimen yaitu 85,71 lebih tinggi drai pada kelas kontrol yang tidak menggunkan media $3 \mathrm{D}$, nilai rata-ratanya 77,5 yang diperoleh setelah kedua kelas diberikan tes hasil belajar dengan butiran soal.

Selain itu analisis inferensial juga menunjukkan fakta yang sama berdasarkan uji t sample independen dengan taraf signifikan $\alpha=0,05$ diperoleh nilai thitung $=13.38$ dimana ttabel $<$ thitung, berarti Ho ditolak maka dapat disimpulkan bahwa hasil belajar kelas eksperimen lebih baik secara signifikan dibandingkan dengan hasil belajar kelas kontrol atau dapat di katakan bahwa media 3D science berbasis android sangat berpengaruh terhadap hasil belajar biologi peserta didik. 
Penggunaan media 3D Science berbasis android terhadap hasil belajar biologi peserta didik pada materi sistem pernafasan mampu mengatasi masalah yang ditemukan peneliti dalam mengajarkan sistem pernafasan. Dengan penggunaan media 3D science berbasis android yang dapat menarik siswa, sehingga siswa menunjukkan minat belajar yang sangat responsif dimana dalam pembelajaran tersebut siswa sangat antusias dengan media 3D Science yang ditampilkan aplikasih android. Dalam satu kelompok siswa yang selesai menyimpulkan materi yang diberikan lewat aplikasi android dapat dijelaskan didepan temanya tentang apa yang telah di diskusikan pada teman kelompoknya.

Kendala-kendala pada saat meneliti di sekolah yaitu: Sikap dan perilaku sebenarnya juga adalah bagian dari karakter yang dimiliki oleh siswa, tetapi ini lebih di fokuskan lagi karena dari semua karakter yang dimiliki oleh siswa, sikap dan perilakulah yang paling berpengaruh dan mempengaruhi budaya siswa di sekolah. Kurangnya disiplin siswa Kedisiplinan merupakan faktor penentuan keberhasilan pembelajaran, disiplin terhadap waktu, disiplin terhadap tugas yang diberikan, disiplin terhadap proses pembelajaran dan lain sebagainya. Mengajar di kelas yang siswanya memiliki tingkat kedisiplinan tinggi lebih menyenangkan dibandingkan dengan mengajar di kelas yang memiliki disiplin rendah. Akan tetapi peneliti tidak boleh menyerah dengan permasalahan ini, peneliti harus mengembalikan kedisiplinan siswa agar pembelajaran berjalan sesuai dengan yang diharapkan. Tidak tenang di dalam kelas Walaupun jumlahnya sangat kecil namun aktivitas ini cukup mengganggu anda dan siswa lainnya. Anda harus menemukan solusinya, jangan terlalu cepat menyalahkan siswa karena boleh jadi sumber masalahnya adalah anda. Misalnya anda mengajar terlalu membosankan, cara anda berkomunikasi tidak jelas, materi terlalu padat, atau situasi lain misalnya ruangan terlalu panas, banyak gangguan dari luar, meja dan kursi tidak menyenangkan dan lain sebagainya. 
Kelebihan media 3D science berbasis android ialah mampu merangsang pesera didik berfikir aktif dalam menggunakan aplikasi yang telah di berikan karna setiap kelompok peserta didik memiliki tanggung jawab untuk menyimpulkan masing-masing dari kelompoknya. Lain halnya dengan pembelajaran menggunakan buku cetak karna kegiatan di dominasi oleh pendidik maka peserta didik yang didajrkan menggunakan buku cetak cenderung merasa jenuh karna hanya bertugas untuk mendengarkan dan mengikuti instruksiyang diberikan. Jika dilihat dari perbedaan keadaan dua kelas tersebut, wajar jika peserta didik yang pembelajaranya menggunakan media 3D science berbasisandroid, miliki hasil belajar yang lebih baik karna dalam prosesnya pun kegiatan belajar yang dilakukan lebih berkualitas.

Penggunaan media pengajaran erat kaitannya dengan tahapan berfikir, sebab melalui media pengajaran hal-hal yanga bstrak dapat dikongkritkan, dan hal-hal yang kompleks dapat disederhanakan. Berdasarkan teori tersebut dapat disimpulkan bahwa media 3D merupakan suatu media yang dapat mengkongkritkan sesuatu yang abstrak. Maka dari itu media 3D layak dijadikan sebagai media pembelajaran alternatif karena dengan penggunaan media pembelajaran ini, siswa dapat berinteraksi langsung dengan media tiruan yang berbentuk aplikasi sehingga pembelajaran akan lebih menarik perhatian siswa dan siswa lebih mudah memahami materi.

Fakta yang ditemukan peneliti Penggunaan media 3D sebelumnya pernah dilakukan oleh Vivi Luthfiah dengan judul "Pengaruh Penggunaan Media Tiga Dimensi Model Tiruan terhadap hasil Belajar Biologi Kelas X Pada Konsep Virus". Yang menyatakan bahwa adanya pengaruh penggunaan model media 3D model tiruan terhadap hasil belajar. Serta Asrotun melakukan penelitian dengan judul "Penggunaan Media Tiga Dimensi Untuk Meningkatkan Hasil Belajar Biologi Siswa”. Kesimpulan dari penelitian ini menunjukkan bahwa penggunaan media tiga dimensi dalam pembelajaran matematika dapat meningkatkan hasil belajar. 
Berdasarkan uraian diatas, terlihan bahwa media pembelajaran 3D science

berbasis

androidmemberikan dampak positif terhadap minat belajar peserta didik dan kemudian mempengaruhi hasil belajarnya. Karna dari hasil analisis desktiptif dan inferensial menunjukkan bahwa hasil belajar biologi pesera didik yang diajarkan menggunkana mrdia 3D lebih baik dibandingkan peseta didik yang diajarkan menggunakan buku cetak, maka dapat disimpulkan bahwa penerapan media 3Dscienceberbasis android memberikan pengaruh terhadap hasil belajar biologi pada penelitian ini yang dapat diduga disebabkan karna penggunaan media pembelajaran tersebut mampu membangkitkan meminat belajar biologi peserta didik kelas VIII A.

\section{KESIMPULAN}

Berdasarkan hasil analisis terhadap data penelitian, diperoleh nilai ratarata hasil belajar IPA biologi siswa yang diajar menggunakan media 3D Science85,71 lebih tinggi dari siswa yang pembelajarannya tidak mengunakan media 3D Science 77,5.Selain itu, hasil pengujian hipotesis menggunakan uji T sampel independen dengan nilai sig (2tailed) 13.38 lebih rendah dari pada $1 / 2 \quad a$ menunjukkan bahwa hasil belajar siswa yang menggunakan media 3D Science ada pengaruh kepada siswa yang diajar menggunakan media 3D Science pada materi sistem pernafasan.

Dengan demikian, diketahui bahwa penerapan media 3D Sciencememberikan pengaruh positif terhadap hasil belajar biologi pada materi sistem Pernafasan manusia.

\section{UCAPAN TERIMA KASIH}

Secara khusus penulis mengucapkan terima kasih yang sebesarbesarnya dengan segenap cinta dan hormatku kepada kedua orang tuaku, kepada ibu Sannang terima kasih yang sebesar-besarnya atas segala do'a, dukungan, kepercayaan yang telah 
diberikan kepada anak Tunggalmu serta

kesabaran ibu dalam mengasuh setelah

berjuang hidup atau mati ketika

melahirkanku. Kepada bapak, Haris

terima kasih yang sebesar-besarnya atas

setiap cucuran keringatmu dalam

menafkahi dan membimbing ku, segala

doa, motivasi, teladan, pengetahuan, dan

dukungan .

\section{DAFTAR PUSTAKA}

Agushinta, Dewi \& Agung Satria .2018.Pembelajaran 3d Sistem Ekskresi Manusia Berbasis Virtual Reality Dan Android. Jurnal Teknologi Informasi dan Ilmu Komputer, vol 5, No 4, hal. 382.

Ali,Sidin \& Khaeruddin.2012.evaluasi pembelajaran.Makassar:Badan Penerbit UNM

Anwar khoirul,sudjimat \& suhartadi .2009.Pengaruh Media Pembelajaran Dua Dimensi, Tiga Dimensi, Dan Bakat Mekanik Terhadap Hasil Belajar Sistem Pengapian Motor Bensin Di Smk Kota Mojokerto.Jurnal teknologi dan keguruaan, vol 32,No 2, hal.142.

Hardiyanto, Rizal Isnanto \& Windasari .2016. Pembuatan Aplikasi Augmented Reality Siklus Hidrologi Sebagai Media Pembelajaran Berbasis Android.Jurnal teknologi dan sistem komputer, vol 4, No 1, hal. 160.

Idaramatasia.2016. Penerapan Model Pembelajaran Kooperatif Tipe Student Teams Achievement Division (STAD) Untuk Meningkatkan Hasil Belajar Fisika Peserta Didik Kelas XI IPA5 SMA Negeri 9 Makassar.JPF, Volume 4, No 1, hal.92.

Luthfiah,Vivi.2013.Pengaruh Penggunaan Media Tiga Dimensi Model Tiruan Terhadap hasil belajar biologi kelas X Pada Konsep Virus .Skripsi pada uin syarif hidayatullah.

Meltzer, D.2002. The Relationship In PhysicsAnd Other Sciences: The Need For Special Science Courses For Teachers. America Jurnal Physics. 58 (8), 734-741.

Muhlis. 2018. Pengaruh Model Pembelajaran Kooperatif Terhadap Motivasi Dan Hasil Belajar Siswa Pada Materi Sistem Koloid SMAN 4 Bantimurung Maros. Jurnal Ilmu Pendidikan, Keguruan, dan Pembelajaran, Volume 2, Nomor 1, hal.14.

Muyaroah,siti \& mega fajartia .2017. Pengembangan media pembelajaran berbasis android dengan menggunakan aplikasi adobe flash DS 6 pada mata pelajaran biologi. Jurnal inovasi kurikulum \& pendidikan teknologi, vol 6,No 2, hal.80.

Nadhiroh,siti. 2017. Pengaruh media komik biologi terhadap hasil belajar siswa SMA 2 Muhammadiya kota Magelang.Skripsi.Yokyakarta: 
Program Studi S1 Uin Sunan Kalijaga Yokyakarta.

Narmawati. 2009. Upaya peningkatan prestasi belajar matematika dengan metode pembelajaran penemuan terbimbing pada peserta didik kelas VSD Negeri 3 Barambang II Kab. Maros. Skripsi tidak dipublikasikan. Maros: Program Pendidikan Biologi STKIP YAPIM Maros.

Nasution, S. 2012. Kurikulum dan penganjaran.Jakarta: BumiAksara.

Nurcahyo, adhi prasetyo .2016. Pengaruh Penggunaan Media Pembelajaran Terhadap Hasil Belajar Siswa Mata Pelajaran Kelistrikan Mesin \& Konversi Energi Di Smk N 2 Depok Yogyakarta:Program Studi Pendidikan Teknik Mesin Fakultas Teknik Universitas Negeri Yogyakarta.

Prasetyo Sigit .2017. Pengembangan Media Pembelajaran Ipa Berbasis Android Untuk Siswa $\mathrm{Sd} / \mathrm{Mi} . J u r n a l$ pedndidikan madrasah ibtidaiyah, vol 1, No 1, hal.125-127.

Putra rizki suhendar, Wijayanti \& Mahatmanti.Pengaruh

Penggunaan Media Pembelajaran Berbasis Aplikasi Android Terhadap Hasil Belajar Siswa.
Jurnal inovasi pendidikan kimia, vol 11, No 2, hal.2010.

Sari

$$
\text { Neptiati }
$$

Norita. 2012.Pengembangan Media Chart Tiga Dimensi (3d) Pembelajaran Menjahit Celana Pada Mata Pelajaran Keterampilan Pkk Siswa Kelas Viii Di Smp N 16 Yogyakarta.Yogyakarta: Program S1 Universitas Negeri Yogyakarta.

Sofia,Siti .2016. Pengaruh penggunaan android dan e-learning terhadap hasil pelajaran IPS siswa kelas VIII SMP Kepanjeng Malang:Program S1Universitas negri malang.

Rosy, Brillian dkk .2018. Pelatihan Media Pembelajaran Berbasis ELearning,

Schoology Bagi Guru SMK Program Keahlian Administrasi Perkantoran Di Kabupaten Jombang Jawa Timur.Jurnal pemberdayaan masyarakat madani, vol 2,No 2, hal.178.

Tirtonegoro. 2001. Belajar dan pembelajaran (Pengertian Hasil Belajar Peserta didik). Jakarta: Grafindo Media Pratama Tirtonegoro. 2001. Belajar dan pembelajaran (Pengertian Hasil Belajar Peserta didik). Jakarta: Grafindo Media Pratama.S 